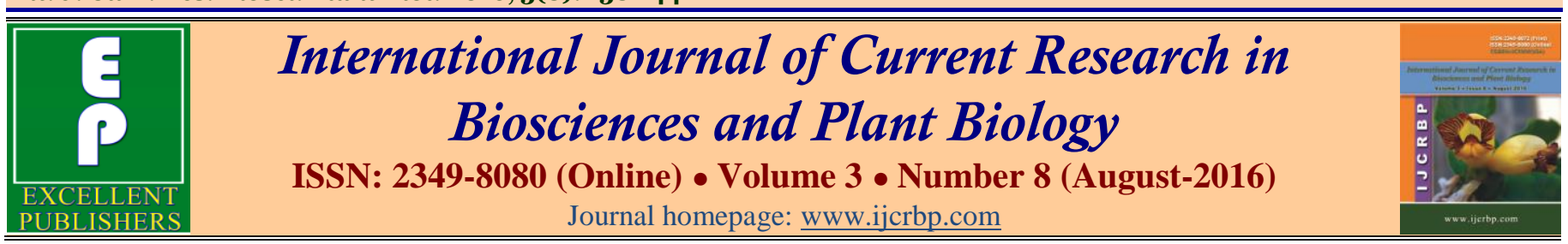

Review Article

doi: http://dx.doi.org/10.20546/ijcrbp.2016.308.021

\title{
Ipomoea carnea Jacq.: Ethnobotany, Phytochemistry and Pharmacological Potential
}

\author{
Satish A. Bhalerao* and Nikhil C. Teli \\ Environmental Sciences Research Laboratory, Department of Botany, Wilson College, Affiliated to University of Mumbai, \\ Mumbai-400 007, India \\ *Corresponding author.
}

\begin{abstract}
A b st ract
Ipomoea carnea Jacq. (Family: Convolvulaceae) commonly known as Bush Morning Glory which is originally from the tropics of South America, grows in dense populations along river beds, river banks, canals and other wetland areas. This evergreen, flowering shrub has been reported to have medicinal properties hence find enormous potential for pharmacological properties such as anti-inflammatory, anti-fungal, hepatoprotective, anti-diabetic, antimicrobial, cardiovascular, anti-oxidant, anxiolytic, immunomodulatory, anti-bacterial, anti-cancer and wound healing activities. It is used indifferent traditional medical systems including Ayurveda, Siddha and Unani. It contains a component identical to marsilin, a sedative and anticonvulsant. Very little is known about the impact of this weed on native flora and fauna in India. It has been reported that the plant possess various bioactive compounds such as glycosides, alkaloids, reducing sugars, flavonoids, fatty acid, esters, alcohol and tannins. The present communication constitutes a review on the medicinal properties, major phytochemical constituents and pharmacological activities of Ipomoea carnea.
\end{abstract}

\section{Article Info \\ Accepted: 21 July 2016 \\ Available Online: 06 August 2016}

\section{Ke y w o r d s}

Anti-oxidant

Ayurveda

Glycosides

Immune-modulatory

Ipomoea carnea

\section{Introduction}

Ipomoea carnea (Family: Convolvulaceae; Fig. 1) which is generally known as Bush Morning Glory. This plant is spread all over the world including American tropics, Argentina, Brazil and Bolivia (Shinners, 1970), Pakistan, Srilanka, etc. (Bhattacharyya, 1976; Mahapata, 1978; Sharma, 1978; Austin and Ghazanfar, 1979; Dassanayake and Fosberg, 1980). It is well distributed in India and found particularly in Chhattisgarh and Madhya Pradesh (Ekka and Dixit, 2007; Dwivedi, 1999; Dwivedi, 2003). In India, it has become a naturalized species invading the wetlands, canals, drain banks, waste lands, field edges and road sides. The plant can propagate both vegetatively by stems which show rooting within a few days and sexually by seeds, and has rapid growth rate (Bhalerao, 1985).
This evergreen, flowering shrub grows to a height of $5 \mathrm{~m}$. The stem is thick and develops into a solid trunk over several years with many branches from base. The stem is erect, woody, hairy, and more or less cylindrical in shape and greenish in colour. It has alternate leaves. Normally it attains $1.25-2.75 \mathrm{~m}$ long and $0.5-0.8 \mathrm{~cm}$ diameter. The leaves are light green, heart shaped or somewhat lanceolate and $10-25 \mathrm{~cm}$ long. The upper surface of leaf is dull green and the lower surface is paler. The leaves which receive lesser sunlight may grow larger than the leaves which receive full sunlight (Afifiet al., 1988; Chaudhuri et al., 1994; Sharma and Bachheti, 2013). The plants bloom in clusters of 4 inch pink flowers all spring and summer long. Flowers of Ipomoea Carnea are axial. The pedicel is green, erect and cylindrical. Its length ranges between $1.5-2.2 \mathrm{~cm}$ and diameter ranges between 
$0.15-0.20 \mathrm{~cm}$. The mouth of the corolla has an entire margin, with slight conspicuous depressions at the points of the cohesion of the petals, measure 5.2-6.0 cm long and 1.6-1.8 cm width at its mouth (Cook, 1987).

The flowers are pale rose, pink or light violet in lax, terminal, pedunculate cymes; fruits have a glabrous capsule; seed is silky. As the name suggests, the blooms fade as the sun warms them, just like morning glories but they are impressive while they last, blooming in large clusters at the ends of the tall branches which is very attractive to butterflies and hummingbirds.

The species is used as folk medicine in traditional medicinal systems including Ayurveda, Siddha, and Unani (Sharma and Bachheti, 2013). Leaves are used as purgative. Leaves paste is applied on 'Haja' (a kind of sore between toes and fingers due to fungal infection). In Brazil, Ipomoea carnea is known as canudo-de-pita, literally "pipe-cane", as its hollow stems were used to make tubes for tobacco pipes. It acts as toxic to cattle. It is reported to have stimulatory allelopathic effects. Roots are boiled to use as laxative and to provoke menstruation. Traditional healers for treatment of skin diseases have used it.

The milky juice of plant has been used for the treatment of leucoderma and other related skin diseases. Only external applications have been recommended due to poisonous nature of the plant. It has depressant effect on central nervous system. Also shows muscle relaxant property (Kumar et al., 2014). The aim of this review is to highlight the traditional uses, phyto-constituents and pharmacological profile of Ipomoea carnea.

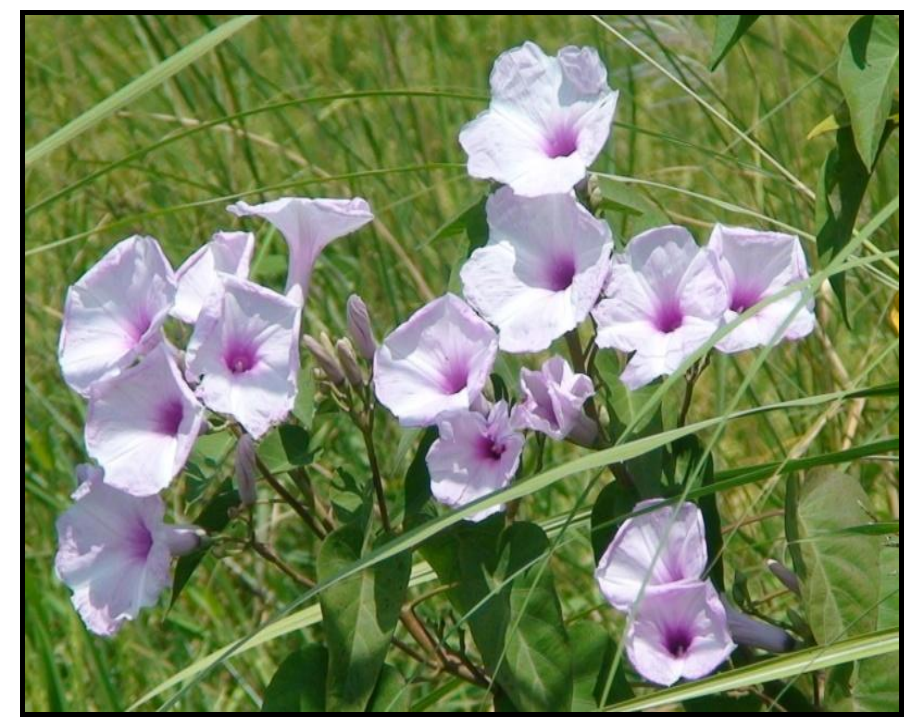

Fig. 1: Ipomea carnea Jacq. in natural environment.
Taxanomic classification (Shrivastava and Shukla, 2015)

$\begin{array}{lll}\text { Kingdom } & : & \text { Plantae } \\ \text { Sub Kingdom } & : & \text { Tracheobionta } \\ \text { Division } & : & \text { Spermatophyta } \\ \text { Subdivision } & : & \text { Magnoliophyta } \\ \text { Class } & : & \text { Magnoliopsida - Dicotyledons } \\ \text { Subclass } & : & \text { Asteridae } \\ \text { Order } & : & \text { Solanales } \\ \text { Family } & : & \text { Convolvulaceae } \\ \text { Genus } & : & \text { Ipomoea } \\ \text { Species } & : & \text { Ipomoea carnea Jacq. }\end{array}$

Vernacular names (Shrivastava and Shukla, 2015)

$\begin{array}{ll}\text { Marathi } & : \text { Beshram } \\ \text { English } & : \text { Bush Morning glory } \\ \text { Hindi } & : \text { Beshram, Behaya } \\ \text { Bengali } & : \text { Beshram } \\ \text { Oriya } & : \text { Behayo } \\ \text { Others } & : \text { Pink Morning Glory, Borrachero, } \\ & \\ & \text { Bush Morning Glory, Badoh Negro, } \\ & \text { Matacabra, Morning Glory Tree }\end{array}$

\section{Traditional uses (ethnobotany)}

The species is used as folk medicine in traditional medicinal systems comprising Ayurveda, Siddha, and Unani (Sharma and Bachheti, 2013). The most efficient use of the species is in skin diseases; particularly the milky juice (latex) of plant is advantageous in treatment of leucoderma (Adsul et al., 2009). The latex is used as an antiseptic for treating lesions in traditional medicines because of its anti-inflammatory effects (Chowdhury et al., 1997). The whole plant extract prepared in hot water is extensively used as an antirheumatic medicine, and the plant is also believed to reduce the teratogenic effect of cyclo-phosphamide (Phillips et al., 1994). In many folk medicines, it is used as aphrodisiac, purgative as well as cathartic (Ved et al., 2004). Antimicrobial and antifungal activities of extracts of the plant have been reported by various workers (Guleria and Kumar, 2006; Adsul et al., 2012). Aqueous extract of the plant demonstrates neuromuscular blocking activity while plant has been proven to have antioxidant, anti-diabetic, wound healing, cardiovascular and hepato-protective activities (Ambiga et al., 2007; Kadiyawala et al., 2012; Sharma and Bachheti, 2013).

It has also been reported as having adverse effects on several animals. Toxic and poisoning effects of leaves on 
the nervous system has been reported very recently (Sharma and Bachheti, 2013). Aqueous extract of leaves has shown embryo-toxic effects in rats resulting in skeletal and visceral abnormalities, malformations and reduced maternal reproductive performance (Hosomi et al., 2008). Furthermore, in African culture, the leaves of Ipomoea carnea are claimed to be effective in the treatment of pile, rheumatic pain, toothache and other inflammatory conditions (Ijeoma et al., 2011). Ijeoma et al. (2011) studied above claims and positively proved that the leaf extract of the plant has anti-nociceptive and anti-inflammatory properties.

The plant extract releases precursor which plays a significant role in the nociceptive mechanism, causing inhibitory effect on pain development process, thus, ameliorating the symptoms associated with various inflammations (Kumar et al., 2014).

\section{Phytochemistry}

Various phytochemical constituents in different parts of Ipomoea carnea is given below.

\begin{tabular}{ll}
\hline Root & The roots are reported to contain 2-Ethyl-1,3-dimethylbenzene, 2-(12-Pentadecynyloxy) tetrahydro- \\
& 2H-pyran, 3-Furanyl[2-hydroxy-4-methyl-2- -(2-methylpropyl) cyclopentyl]- methanone, 2,2- \\
Dideuterooctadecanal, Hexadecanoic acid, Linoleic acid (Sahayaraj et al., 2014). \\
Stem \\
The stem of the plant contains 2-(12-Pentadecynyloxy) tetrahydro- 2H-pyran, 1-Octadecanol, \\
Hexadecanoic acid, Epiglobulol, Squalene, 1-Octadecanol (Sahayaraj et al., 2014). \\
The leaves of the plant showed the presence of thirteen compounds which include hexa decanoic acid, \\
stearic acid, 1, 2 diethyl phthalate, n-octadecanol, octacosane, hexatriacontane, tetracontane, 3- \\
diethylamino-1- propanol (Tirkey et al.,1988; Vaishali et al., 2009). Also the presence of swainsonine \\
and calystegines B1, B2, B3, and C1 were detected in the aqueous ethanolic extract of leaf (Balogh \\
et al., 1999). \\
The flowers of the plant are reported to contain flavonoids, tannins, glycosides, alkaloids, \\
carbohydrates and phenolic compound (Gupta et al., 2010). The presence of swainsonine and \\
calystegines B1, B2, B3, and C1 confirmed in the aqueous ethanolic extract of flowers (Balogh et al., \\
1999). \\
Presence of swainsonine and calystegines B1, B2, B3, and C1 are found in seeds of the plant Ipomoea \\
carnea (Balogh et al., 1999).
\end{tabular}

\section{Pharmacological potential}

\section{Antioxidant activity}

It was studied that the methanolic extract of Ipomoea carnea was dissolved in distilled water and partitioned with $n$-hexane, chloroform, ethyl acetate and $n$-butanol consecutively. The antioxidant potential of all these fractions and remaining aqueous fraction was assessed by four methods: DPPH free radical scavenging activity, total antioxidant activity, FRAP assay and ferric thiocyanate assay and total phenolics were also determined. It was found that the percentage inhibition of DPPH radical was highest for n-Butanol fraction $(91.11 \%$ \} 0.68$)$, total antioxidant activity was highest for chloroform (0.9096 0.1$)$. FRAP value was highest for ethyl acetate fraction (511.99\} $1.8 \quad \mu \mathrm{g}$ of troloxequivalents). Total phenolic contents were maximum for chloroform fraction (113.05\} $1.2 \mathrm{mg}$ of gallic acid equivalents) (Abbasi et al., 2010; Gaur et al., 2009; Adsul et al., 2012).

\section{Wound healing activity}

Ambiga et al. (2007) reported when fresh flowers of Ipomoea carnea extracted with $95 \%$ ethanol and the extract was concentrated in vacuum and the aqueous concentrate was treated with successive fraction of various solvents viz., diethyl ether, chloroform and ethyl acetate. The fresh flowers of Ipomoea carnea contain Kaempferol and its $3-O-\beta-D$ glucoside. These were known to retain considerable wound healing activity. Wound healing normally involves an initial inflammatory phase followed by fibroblast proliferation, formation of collagen fibres and shrinking and drying of the scar. These phases are simultaneous but independent of each other. These activities are comparable to Sulphathiazole and considerably improved than untreated wounds.

\section{Antidiabetic activity}

The study revealed that when antdiabetic property of Ipomoea carnea leaves were carried out in normal rats 
and in streptozotocin induced diabetic rats; the aqueous extract of Ipomoea carnea considerably reduces the blood glucose level of rats. It increases the glucose tolerance in normal rats (Kadiyawala et al., 2012).

\section{Antifungal activity}

Antifungal activity of Ipomoea carnea has been demonstrated against Alternaria alternata and Curvularia lunata (Agarwal and Uppadhay, 1997). Chloroform and Methanol extract of Ipomoea carnea revealed antifungal activity against eleven pathogenic and non-pathogenic fungi (Ikeda, et al., 2003). Antifungal fractions of the leaves of Ipomoea carnea were attained using Colletotrichumg loeosporioide sand Cladosporium cucumerinum as test organisms. Thea ctivity of the purified fraction was further established by the dose dependent inhibition of the spore germination of Alternaria alternata and A. porri. The active fraction was recognized as a mixture of (E)-octadecyl pcoumarate and (Z)-octadecyl p-coumarate (Nidiry et al., 2011).

\section{Anti-inflammatory activity}

Aqueous extracts of mature green leaves of Ipomoea carnea were tested for anti-inflammatory activity. The extracts were used at a dose of $250 \mathrm{mg} / \mathrm{kg}$ and $500 \mathrm{mg} / \mathrm{kg}$ body weight. The study concluded that Ipomoea carnea leaves possess a strong anti-inflammatory activity at dose of $500 \mathrm{mg} / \mathrm{kg}$ and possesses better result as compared to Etoricoxib $6 \mathrm{mg} / \mathrm{kg}$ (Khalid et al., 2011).

\section{Hepatoprotective activity}

Ipomoea carnea can be a favourable bioactive substance for prevention and treatment of liver injury (Gupta et al., 2012). Ipomoea carnea holds good hepatoprotective activity using $\mathrm{CCl}_{4}$ induced hepatotoxicity in rat. This hepatotoxicity is due to free radical $\mathrm{CCl}_{3}$ which is metabolite. It lessens alkalization of cellular proteins and other macromolecules with simultaneous attack on polyunsaturated fatty acids to produce lipid peroxide (Bishayee et al., 1995).

\section{Glycosidase inhibitory activities}

Analysis of Ipomoea carnea plant material was carried out by gas chromatography-mass spectrometry recognised the presence of the mannosidase inhibitor swainsonine and 2 glycosidase inhibitors, calystegine B2 and calystegine $\mathrm{C} 1$, consistent with a plant-induced a- mannosidosis in the goats. The described storage disorder is analogous to the lysosomal storage diseases induced by ingestion of locoweeds (Astragalus and Oxytropis) and poison peas (Swainsona) (Balogh et al., 1999). Ipomoea carnea makes guinea pigs a valuable animal model for the reproduction of induced alphamannosidosis (Cholich et al., 2009).

\section{Anti-cancer activity}

In in-vitro and in-vivo studies it was found that hydroalcoholic extract of Ipomoea carnea leaves possess substantial anticancer property with the dose dependent effect. This may probably due to the presence of phytochemicals such as alkaloids, phenols and flavonoids (Kumar et al., 2013).

\section{Immunomodulatory activity}

Toxic component in it are- the nortropane alkaloid calystegines B1, B2, B3 and C1 and the indolizidine alkaloid swainsonine (SW) (Cook, 1987; Sahayaraj and Ravi, 2008). Effects of swainsonine (SW) in female rats were found that reduction in body, increase in spleen/body weight ratio, decrease in the thymus/body weight ratio and histological changes. When pregnant rats were treated with $7 \mathrm{gm} / \mathrm{kg}$ of Ipomoea carnea AF, all of the litters died immediately after birth. Rats consume considerably less food due to effect of Ipomoea carnea. Swainsonine has immune effect due to glycoprotein metabolism. Due to this rheumatoid arthritis (RA) was developed to both adult (70 days old) and juvenile rats (21 days old). Hence swainsonine modulates the immune function (Rosenberg, 1999; Lunardi et al., 2000).

\section{Anxiolytic activity}

Ipomoea carnea seems to fall under the sedativehypnotic category of central depressants activity. The anxiolytic effects of the aqueous and methanolic extract of Ipomoea carnea leaves (32.50 and $16.25 \mathrm{mg} / \mathrm{kg}$ i.p.) was assessed in mice using elevated plus maze, open field test and hole board test models, diazepam was used as positive standard. The intra-peritoneal (i.p.) LD50 of the Ipomoea carnea leaf aqueous extract (ICLAE) and Ipomoea carnea methanolic extract (ICLME) in mice was found to be $325 \mathrm{mg} / \mathrm{kg}$ i.p. body weight. ICLME exhibited greater anxiolytic effect as compared to ICLAE (doses of $32.5 \mathrm{mg} / \mathrm{kg}$ and $16.2 \mathrm{mg} / \mathrm{kg}$ ) and diazepam. The effect of the ICLAE and ICLME revealed a dose dependent significant increased the number of head 
dipping behaviour in whole board test at doses 32.5 and $16.2 \mathrm{mg} / \mathrm{kg}$ when compared with control and diazepam $1 \mathrm{mg} / \mathrm{kg}, 2 \mathrm{mg} / \mathrm{kg}$ as a standard. These observations indicate that ICLAE and ICLME showed an anxiolytic activity (Bidkar et al., 2012). In experimental studies in which the plant was given to adult goats, all animals showed disorders of behaviours and consciousness as well as abnormalities of goat (ability to stand and posture) and one goat died (Tokarnia et al., 2002; Rout et al., 2013).

\section{Antimicrobial activity}

In one study n- hexane, ethyl acetate, acetone, ethanol and acetone fraction extract were prepared from Ipomoea carnea leaves. Crude acetone extracts revealed activity against Proteus vulgaris and Salmonella typhimurium, while the crude ethanol extract explicates antimicrobial activity against Pseudomonas aeruginosa. This was the first report showing inhibition of Proteus vulgaris and Salmonella typhimurium by the acetone extract while ethanol extract exhibits promising inhibition against pseudomonas aeruginosa of Ipomoea carnea leaves (Adsul et al., 2012). A secondary metabolite dibutyl phthalate isolated from stem of Ipomoea carnea has also been recorded for antibacterial activity (Khatiwora et al., 2012).

\section{Cardiovascular activity}

When aqueous extract of Ipomoea carnea was hosted to isolated frog heart then initial blockade for 5-10 seconds was observed. When dose increased then the timing increased up to 2 minutes. It might be due to Ipomoea carnea produces a positive inotropic effect on isolated frog heart by sodium extrusion or release of the intracellular calcium (Bachhav et al., 1999). When atropine $1 \mu \mathrm{g} / \mathrm{ml}$ was introduced in extract then the initial different phase was blocked used stimulant effect become stronger.

\section{Mosquitocidal activity}

Synergistic effect of insecticides with plant extracts of Ipomoea carnea is reported against malarial vector, Anopheles stephensi has been reported (Kuppusamy and Manoharan, 1992).

\section{Conclusion}

The medicinal importance of the plant as discussed above evidently proves that Ipomoea carnea Jacq. is one of the most promising shrub which possess a lot of therapeutic values. The present literature survey revealed that the plant Ipomoea carnea is a foundation of pharmacologically and medicinally vital phytoconstituents hence this plant has shown tremendous applications in both traditional as well as modern medical practices. Several mechanisms are likely to account for the observed pharmacological effects, the most important being the antimicrobial, antidiabetic, anti-inflammatory, antioxidant, antifungal, wound healing, cardiovascular, glycosidase inhibitory, anticancer, anxiolytic, mosquitocidal, immuno-modulatory, hepatoprotective activity. In future the standardization and stabilization studies on Ipomoea carnea need to be carried out which can help in proving it to be a promising source in pharmaceutical industry. It is also significant to recognize that its extract may be effective not only in the isolation but may have modulating effect when used in combination with other drug.

\section{Conflict of interest statement}

Authors declare that they have no conflict of interest.

\section{Acknowledgement}

The authors would like to express their sincere gratitude to Dr. V.J. Sirwaiya, Principal, Wilson College for their administrative support, co-operation and help.

\section{References}

Abbasi, M.A., Zafar, A., Riaz, T., Rehman, A., Arshad, S., Shahwar, D., Jahangir, M., Siddiqui, S.Z., Shahzadi, T., Ajaib, M., 2010. Evaluation of comparative antioxidant potential of aqueous and organic fractions of Ipomoea carnea. J. Med. Plants Res. 4(18), 1883-1887.

Adsul, V.B., Khatiwora, E., Torane, R., Deshpande, N.R., 2012. Antimicrobial activities of Ipomoea carnea leaves. J. Nat. Prod. Plant Resour. 2(5), 597-600.

Adsul, V.B., Khatiwora, E., Deshpande, N.R., 2012. Evaluation of antioxidant activity of Ipomoea carnea leaves. J. Nat. Prod. Plant Resour. 2(5), 584-588.

Afifi, M.S., Amer, M.M.A., El-Khayat, S.A., 1988. Macro-and micro morphology of Ipomoea carnea Jacq. Growing in Egypt. Part I. Leaf and flower. Mansoura J. Pharmaceut. Sci. 3, 41-57.

Agarwal, R. K., Uppadhay, R.K., 1997. Antimicrobial activity of metal complexes prepared from the leaf proteins of Ipomoea carnea Jacq. Indian Drugs Phar. Ind. 14(2), 23-25.

Ambiga, S., Narayanan, R., Gowri, D., Sukumar, D., Madhavan, S., 2007. Evaluation of wound healing activity of flavonoids from Ipomoea carnea Jacq. Anc. Sci. Life. 26(3), 45-51. 
Anand, G., Sumithira, G., Chinna, R.R., Muthukumar, A., Vidhya, G., 2013. In vitro and in vivo anticancer activity of hydroalcoholic extract of Ipomoea carnea leaf against Ehrlich Ascites Carcinoma cell lines. Int. J. Adv. Pharm. Gen. Res. 1(1), 39-54.

Austin, D.F., Ghazanfar, S., 1979. Convolvulaceae. Flora of West Pakistan. (Eds.: Nasir, E., Ali, S.I.). Agricultural Research Council, Islamabad. pp.1-64.

Bachhav, K.V., Burande, M.D., Rangari, V.D., Mehta, J.K., 1999. Effect of aqueous extract of Ipomoea carnea leaf on isolated frog and mouse heart. Ind. J. Exp. Biol. 37(11), 1080-1084.

Balogh, De., Dimande, K.K.I.M., Van der Lugt, A.P., Molyneux, J.J., Naude, R.J., Welman, T.W., 1999. lysosomal storage disease induced by Ipomoea carnea in goats in Mozambique. J. Vet. Diagn. In Vest. 11, 266-273.

Bhalerao, S. A., 1985. Role of Ipomoea carnea Jacq. in disturbed habitats. Ph.D. thesis to the University of Mumbai.

Bhattacharyya, P.K., 1976. A note on two species of Ipomoea, namely Ipomoea carnea Jacq. and Ipomoea fistulosa Mart. Ex Choisy in Eastern Asia. J. Bombay Nat. Hist. Soc. 73, 317-320.

Bidkar, J.S., Bhujbal, M.D., Ghanwat, D.D., Dama, G.Y., 2012. Anxiolytic activity of aqueous and methanolic extracts of Ipomoea carnea leaves. Int. J. Universal Pharm. Bio Sci. 1(2), 1-11.

Bishayee, A., Sarkar, A., Chatterjee, M., 1995. The hepatoprotective activity of carrot (Daucus carota L.) against carbon tetrachloride intoxication in mouse liver. J. Ethnopharmacol. 47, 69-74.

Cholich, L.A., Gimeno, E.J., Teibler, P.G., Jorge, N.L., 2009. The guinea pig as an animal model for Ipomoea carnea induced alpha-mannosidosis. Taxacon Int. Soc. Toxinol. 54, 3-7.

Chowdhury, A.K.A., Ali, M.S., Khan, M.O.F., 1997. Antimicrobial activity of Ipomoea fistulosa extractives. Fitoterapia. 68(4), 379-380.

Cook, C. D. K., 1987. Ipomoea fistulosa: A new problem for India. Aquaphyte J. 7(1), 12.

Dassanayake, M. D., Fosberg, F.R., 1980. A Revised Handbook to "The Flora of Ceylon".Vol 1. Amerind Publishing Co. Pvt. Ltd., New Delhi. 508p.

Dwivedi, S.N., 1999. Traditional health care among the tribals of Rewa District of Madhya Pradesh with special reference to conservation of endangered and vulnerable species. Econ. Taxon Bot. 23(2), 315-320.

Ekka, R.N., Dixit, V.K., 2007. Ethnopharmacognostical studies of medicinal plants of Jashpur district Chattisgarh. Int. J. Green Pharm. 1(1), 2-4.

Gaur, L.B., Singh, S.P., Gaur, S.C., Saxesena, R.R., Parveen, S., Kumar, S., 2014. Facts with therapeutic significance of Ipomoea carnea. Punarnav. 2(1), 141-146.

Guleria, S., Kumar, A., 2006. Antifungal activity of some Himalayan medicinal plants using direct bioautography. J. Cell Mol. Biol. 5, 95-98.

Gupta, A., Nayak, S., Mallik, A., 2010. Preliminary phytochemical screening of hydroalcoholic flower extract of Ipomoea fistulosa. Int. J. Curr. Trends Sci. Tech. 1(2), 37-40.

Hosomi, R.Z., De'Souza, H., Górniak, S.L., Habr, S.F., Penteado, S.W., Varoli, F.M.F., Bernardi, M.M., 2008. Embryotoxic effects of prenatal treatment with Ipomoea carnea aqueous fraction in rats. Braz. J. Vet. Res. Anim. Sci. 45(1), 67-75.

Ijeoma, U.F., Aderonke, S.O., Ogbonna, O., Augustina, M.A., Ifeyinwa, C.N., 2011. Antinociceptive and anti inflammatory activities of crude extracts of Ipomoea involucrata leave in mice and rats. Asian Pac. J. Trop. Med. 4(2), 121-124.

Ikeda, K., Kato, A., Adachi, I., Haraguchi, M., Asano, N.J., 2003. Alkaloids from the poisonous plant Ipomea carnea effects on intracellular lysosomal glycosidase activity in human lymphoblast cultures. Agric. Food Chem. 51, 7642-7646.

Kadiyawala, A.L.A., Prasad, A.K., Kumar, S., Iyer, S.V., Patel, H.A., Patel, J.A., 2012. Comparative antidiabetic studies of leaves of Ipomoea carnea and Grewia asiatica on streptozotocin induced diabetic rats. Int. J. Pharmaceut. Biol. Arch. 3(4), 853-857.

Khalid, Md. S., Singh, R.K., Reddy, I.V.N., Kumar, S.J., Kumar, B.S., Kumar, G.N.S., Rao, S.K., 2011. Anti Inflammatory activity of aqueous extract of Ipomoea carnea Jacq. Pharmacol. Online. 1, 326-331.

Khatiwora, E., Adsula, V.B., Kulkarni, M., Deshpande, N.R., Kashalkar, R.V., 2013. Isolation and characterization of substituted dibutyl phthalate from Ipomoea carnea stem. Der PharmaChemica. 5(5), 5-10.

Kumar, A., Manral, U., Sharma, S., 2014. Traditional remedy for Muscle Strain Using Ipomoea carnea Jacq. and Ricinus communis L. leaves in Haryana, India. Int. J. Med. Plants. 108, 625-631.

Kuppusamy, A., Manoharan, T., 1992. Synergistic effect of insecticides with plant extracts against malarial vector, Anopheles stephensi. Trends Life Sci. 7(1), 39-42.

Lunardi, C., Bason, C., Navone, R., Millo, E., Damonte, G., Corrocher, R., 2000. Systemic sclerosis immunoglobulin $\mathrm{G}$ autoantibodies bind the human cytomegalovirus late roteinUL94 and induce apoptosis in human endothelial cells. Nat. Med. 6, 1183-1186.

Mahapata, A. K., 1978. A brief survey of some unrecorded, less known and threatened plant species of Sundarban of West Bengal. Bull. Bot. Soc. Bengal. 32, 54-58.

Nidiry, E. S., Ganeshan, G., Lokesha, A.N., 2011. Antifungal activity and isomerization of octadecyl p-coumarates from Ipomoea carnea subsp. fistulosa. Nat. Prod. Commun, 6(12), 1889-1892.

Phillips, O., Gentry, A.H., Reynal, L., Wilkin, P., Gulvez, D.C.B., 1994. Quantitative ethnobotany and Amazonian conservation. Conserv. Biol. 8(1), 225-248.

Rosenberg, A., 1999. Bones, joints and soft tissue tumors. (Eds.: Cotran, R.S., Kumar, V., Colins, T.) Robbins Pathologic Basis of Disease. WB Saunders Company, Pennsylvania. pp.1215-1268. 
Rout, S.K., Kar, D.M., 2013. Sedative, anxiolytic and anticonvulsant effects of different extracts from the leaves of Ipomoea carnea in experimental animals. Int. J. Drug Dev. Res. 5(2), 232-243.

Sahayaraj, K., Ravi, C., 2008. Preliminary phytochemistry of Ipomea carnea Jacq. and Vitex negundo Linn. leaves. Int. J. Chem. Sci. 6(1), 1-6.

Sahayaraj, K., Kombiah, P., Dikshit, A. K., Rathi, M., 2015. Chemical constituents of the essential oils of Tephrosia purpurea and Ipomoea carnea and their repellent activity against Odoiporus longicollis. J. Serb. Chem. Soc. 80(4), 465-473.

Sharma, A., Bachheti, R. K., 2013. A review on Ipomoea carnea. Int. J. Pharm. Bio Sci. 4(4), 363-377.

Sharma, M., 1978. Aquatic and marshy angiosperms of
Punjab. Bull. Bot. Soc. Bengal. 31, 52-60.

Shinners, L.H., 1970. Manual of the Vascular Plants of Texas. (Eds.: Correll, D.S., Johnston, M.C.), Renner, Texas. pp.1241-1261.

Shrivastava, D., Shukla, K., 2015. Pharmaceutical efficacy of Ipomoea carnea. Biol. Forum - Int. J. 7(1), 225-235.

Tirkey, K., Yadava, R.P., Mandal, T.K., Banerjee, N.L., 1988. The pharmacology of Ipomoea carnea. Ind. Vetn. J. 65, 206-210.

Tokarnia, C.H., Dobereiner, J., Peixoto, P.V., 2002. Poisonous plants affecting livestock in Brazil. Toxicon. 40, 1635-1660.

Ved, G.A., Kinhal, K., Ravikumar, M.K., Vijaya, S., Indresha, J.H., 2004. Threat Assessment and Management Prioritization for Medicinal Plants of Chattisgarh and Madhya Pradesh, FRLHT, Bangalore, India. 418p.

\section{How to cite this article:}

Bhalerao, S. A., Teli, N. C., 2016. Ipomoea carnea Jacq.: Ethnobotany, phytochemistry and pharmacological potential. Int. J. Curr. Res. Biosci. Plant Biol. 3(8), 138-144. doi: http://dx.doi.org/10.20546/ijcrbp.2016.308.021 